\title{
CONFLICT BETWEEN PARTICIPATORY AND REPRESENTATIVE DEMOCRACY: A CALL FOR MODEL LEGISLATION ON PUBLIC PARTICIPATION IN THE LAW-MAKING PROCESS IN SOUTH AFRICA
}

\author{
Moses Retselisitsoe Phooko* \\ LLB (Hons), Diploma in Human Rights, \\ LLM in International Human Rights Law, and LLD \\ in International Law \\ Professor of International Law \\ Department of Legal Pluralism and Jurisprudence \\ Criminal Law and Procedure \\ University of Limpopo, Turfloop Campus
}

\section{SUMMARY}

The Constitution of the Republic of South Africa, $1996^{1}$ mandates legislatures at various levels of government to ensure public participation in the law-making process. The Constitution, however, does not map out the parameters of public participation as far as the law-making process is concerned. Thus, a number of questions remain largely unanswered. For instance, does public participation merely constitute consulting with the people? Does it, perhaps, go as far as to require the legislature to consider the views of the people? Supposing the views of the people are considered, does public participation suggest that the end results of the consultation process should reflect the views of the people? As the answers to the foregoing questions are far from conclusive, the aim of this paper is to critically examine the nature of the relationship between participatory and representative democracy in the law-making process in order to ascertain how the courts have resolved conflicts that involve the previously mentioned forms of democracy. This will be done through examining various court cases in which their own elected

Former law clerk, Constitutional Court of South Africa, Advocate of the High Court of South Africa. This paper is based on a paper presented at the 2014 International Journal of Arts \& Sciences annual conference held at the Joseph B. Martin Conference Center at Harvard Medical School, 77 Avenue Louis Pasteur, Boston, Massachusetts. The author is grateful to the UNISA College of Law Research Committee for sponsoring the trip to attend the conference. The views expressed and any errors are those of the author.

Hereinafter "the Constitution". 
representatives disregarded the views of the electorate. The argument presented in this paper is that participatory and representative democracies are in conflict with each other. The paper further advocates for the adoption of model legislation on public participation in the law-making process.

\section{$1 \quad$ INTRODUCTION}

The history of South Africa is an unpleasant one. It was based on the suppression of majority views in matters that fundamentally affected their day-to-day lives. ${ }^{2}$ This suppression was founded on various laws, which were enacted by the apartheid government. ${ }^{3}$ When it came to the participation of the public in law-making processes, this government "created race-based municipalities [in order] to facilitate and regulate the suppression of participation by... [black people]". ${ }^{4}$ There was little or no space for meaningful public participation for the broader community. Mahomed DP narrates the suffering and suppression of the views of the majority people as follows:

"For decades South African history has been dominated by a deep conflict between a minority which reserved for itself all control over the political instruments of the state and a majority who sought to resist that domination. Fundamental human rights became a major casualty of this conflict as the resistance of those punished by their denial was met by laws designed to counter the effectiveness of such resistance..."

The ease with which the apartheid government used to disregard public participation in the law-making process can be attributed to the absence of constitutional safeguards that promoted the right of the people to have a say in the law-making process. ${ }^{6}$ This is no longer the position as the Constitution clearly states that the "government is based on the will of the people". Additionally, the Constitution places a duty on various spheres of government to facilitate public participation in the law-making process. ${ }^{8}$ Section 59(1)(a) of the Constitution requires the National Assembly to involve the people in its processes such as the law-making system. Section 72(1)(a) also requires the National Council of Provinces (hereinafter "the NCOP") to make people part of the legislative and other processes by considering their inputs. Furthermore, section 118(1)(a) of the Constitution requires a provincial legislature to solicit the views of the public in legislative processes. It is evident that the post-apartheid government has

2 Nyalunga "An Enabling Environment for Public Participation in Local Government" 2006 International NGO Journal 1.

3 See for eg, the Group Areas Act 41 of 1950 and the Reservation of Separate Amenities Act 49 of 1953 that were promulgated to reserve certain areas and amenities for a specific race. Nyalunga 2006 International NGO Journal 1.

5 Azanian Peoples Organization (AZAPO) v President of the Republic of South Africa 1996 (4) SA 672 par 1 (author's own emphasis added).

6 Williams "Community Participation and Democratic Practice in Post-Apartheid South Africa: Rhetoric vs Reality" http://www.drc-citizenship.org/system/assets/1052734456/original /1052734456-williams.2005-community.pdf?1289491529 (2015-01-28).

7 Preamble to the Constitution.

8 S 59(1), 72(1), 118(1), 42(3) and (4) of the Constitution. 
recognised that public participation in the law-making process is a critical factor in a constitutional democracy.

Despite the fact that there are constitutional provisions requiring the public to be consulted in the law-making process, there is no universal consensus on the definition of public participation. At the very least, it would have sufficed to have some form of guidance about what the relevant constitutional provisions entail. The fact that the Constitution does not elaborate further on this notion leaves the concerned organs without any guidance on how to implement the relevant sections of the Constitution. This then begs the question, is there, perhaps, a need for specific legislation to address this gap? This question will be answered later in the discussion. At the very least, the Constitutional Court of South Africa in Doctors for Life International $v$ Speaker of the National Assembly said that public participation in legislative making process entails giving an opportunity to those who are likely to be adversely affected by the draft law to make representations either orally or in writing. ${ }^{9}$ This process requires a meaningful engagement with the public in order to understand what their views or wishes are or may be. This is with a view to ensuring that laws or policies reflect the views of the public. ${ }^{10}$ This highlights South Africa's constitutional democracy that is both representative and participatory in nature. ${ }^{11}$

Representative democracy is exercised through those who are democratically elected by the people and is exercised through regular elections. ${ }^{12}$ The electorate elects their representatives to act and decide on their behalf because it is impractical for the public to directly take part in the daily management of public affairs. ${ }^{13}$ Participatory democracy entails making representations in the law-making process from the onset and taking part in the decision-making processes. ${ }^{14}$ This is where the electorate voices their inputs in the proposed law or policy and indicates whether or partially in support or opposed to the legislation. Further, this is where the constituency submits what the proposed law should contain and how a particular issue should be regulated. It must be noted, "[c]onsultation does not necessarily require reaching an agreement." ${ }^{15}$

There have been a series of cases where the Constitutional Court has ruled that facilitating public participation means that the policy should be

9 Doctors for Life International $v$ Speaker of the National Assembly 2006 (12) BCLR 1399 (CC) par 1408-1409J.

10 Phooko "What Should be the Form of Public Participation in the Law-Making Process? An Analysis of South African Cases" 201435 Obiter 41.

11 Nyati "Public Participation: What has the Constitutional Court Given the Public?" 200812 Law, Democracy and Development 102.

12 Ibid.

13 Nyirabikali "Participatory Democracy, Pluralistic Governance and Peace Education for Leaders: Lessons from the Kenyan Case" 20082 Conflict Trends 36.

14 Chenwi "Meaningful Engagement in the Realisation of Socio-economic Rights: The South African Experience" 201126 South African Public Law Journal 129; Rosa "Transformative Constitutionalism in a Transformative Developmental State" 20113 Stell LR 546.

15 Phooko 201435 Obiter 9. 
informed by the views of the people. ${ }^{16}$ However, the court has also held that facilitating public participation does not necessarily mean that the views of the people will reflect the outcome. ${ }^{17}$ There appears to be a conflict between representative and participatory democracies as the electorate in some of the cases feels aggrieved by the elected representative's failure to consider their views. As a result, they find themselves with no remedy. The elected representatives, on one hand, feel that they have complied with their duty to facilitate public participation even though the outcome does not reflect the views of the electorate. The Constitutional Court of South Africa has to this end said that the place for contesting government policy is the political field, not the courts. ${ }^{18} \mid$ will explore the court's position in the course of this discussion.

The paper examines the nature of the relationship between participatory and representative democracy in the law-making process by discussing various court cases in which the views of the electorate were disregarded by their own elected representatives. ${ }^{19}$ Reference to the Taxation Laws Amendment $\mathrm{Act}^{20}$ and the Tax Administration Laws Amendment $\mathrm{Act}^{21}$ will also be made only to the extent relevant. The paper will also discuss case law to determine whether participatory or representative democracy seems to be favoured by the courts. If the finding is that there are no clear guidelines for the form of participation, the paper will propose the enactment of legislation to standardise the form that public consultation should take at a local government level in the law-making process. The minimum content for such legislation will also be considered. These previously mentioned cases are selected because they show a conflict between representative and participatory democracies. It is argued that representative and participatory democracy should be in conflict with each other but complement each other.

\section{REPRESENTATIVE DEMOCRACY PREFERRED OVER PARTICIPATORY DEMOCRACY}

This section discusses some of the cases wherein the elected representatives consulted with the people but there was no consensus. The questions to be asked are; (a) where there is a conflict between the views of representatives and the electorate, whose views should take precedence/prevail? (b) Whether the elected representatives may unilaterally deviate from the views expressed by their constituencies, and (c)

16 See, inter alia, Merafong Demarcation Forum $v$ President of the Republic of South Africa 2008 (10) BCLR 968 (CC); Matatiele Municipality v President of the Republic of South Africa (2) 2007 (1) BCLR 47 (CC); Doctors for Life International $v$ Speaker of the National Assembly supra.

17 Merafong Demarcation Forum v President of the Republic of South Africa supra par 50.

18 National Treasury v Opposition to Urban Tolling Alliance 2012 (6) SA 223 (CC) par 293.

19 National Treasury $v$ Opposition to Urban Tolling Alliance [2013] 4 All SA 639 (SCA); Matatiele Municipality $v$ President of the Republic of South Africa supra; Poverty Alleviation Network v President of the Republic of South Africa 2010 (6) BCLR 520 (CC).

2025 of 2015.

2123 of 2015 . 
whether the elected representatives may act unilaterally so without being subject to public accountability? These are some of the questions that this part addresses. This is done by discussing and analysing decided cases that were brought before the courts because of allegations that there was a failure to consult with the people. These cases are selected because the courts appear to have on one hand promoted participatory democracy and on the other seemed to be placing more emphasis on representative democracy.

\section{The Opposition to Urban Tolling Alliance $v$ The South African National Roads Agency Ltd (SCA)}

The applicants, in this case, included individuals and business people who challenged the Government's law for collecting revenue through the "userpays" tolling system of Gauteng freeways. The freeway was upgraded by the South African National Road Agency. A number of public hearings were held and the public indicated that they do not want the tolling system. ${ }^{22}$ Despite vehement oppositions to the tolling system, the Government went ahead to operationalize the "user-pays" system. This case could be seen as a matter wherein the people's views are disregarded despite being clearly opposed to the tolling system. It must be mentioned that this case was dismissed on technical grounds because the applicants had brought their case before the court five years after the tolling system was launched. ${ }^{23}$ The court indicated that the project was already completed and that there was no plan B to replace the tolling system. ${ }^{24}$ However, it is imperative to note that throughout the five-year period, the people had always engaged the government through public demonstrations and public hearings to communicate their opposition to the tolling system. ${ }^{25}$ The court rather concentrated on technical grounds instead of considering what the peoples' views had been since the proposal and inception of the e-tolls. Indeed, the court was not prepared to venture into details on why the views of the people were disregarded. The basis for this is that in a similar case which involved e-tolling, and where the decision to temporarily stop the operation of e-tolls was overturned, the court made it clear that "the playing field for the contestation of executive government policy is the political process, not the judicial one". ${ }^{26}$ This further indicates that where the elected representatives have adhered to the law and conducted public participation, they may still do anything they wish regardless of what the views of the people are. As the requirement for conducting public participation was met, the electorate will be unable to challenge the decision, as the courts are not prepared to deal with issues

22 The Opposition to Urban Tolling Alliance $v$ The South African National Roads Agency Ltd [2013] 4 All SA 639 (SCA) par 13.

23 The Opposition to Urban Tolling Alliance $v$ The South African National Roads Agency Ltd supra par 31.

24 Ibid.

25 Phooko 201435 Obiter 51.

26 National Treasury v Opposition to Urban Tolling Alliance 2012 (6) SA 223 (CC) par 93. 
that do not fall within their sphere of operation unless such decisions were taken irrationally. ${ }^{27}$

\section{Merafong Demarcation Forum $v$ President of the Republic of South Africa ${ }^{28}$}

This case concerned the Constitution Twelfth Amendment of 2005, which altered provincial boundaries and relocated the Merafong City Local Municipality from Gauteng Province to the North West Province. ${ }^{29}$ Those who resided in Gauteng were extremely dissatisfied by the effect of the aforesaid legislation. The applicants sought relief from the court on the grounds that the Twelfth Amendment of 2005 was enacted in a manner that had excluded public participation. The court had to inter alia decide whether the Gauteng Provincial Legislature had complied with its constitutional obligation to facilitate public involvement when it "considered and approved that part of the Twelfth Amendment of 2005 which concerned Merafong City Local Municipality". ${ }^{30}$

During the public hearings, the people of Merafong were against their relocation to the Province of North West. On the basis of this opposition, a "negotiating mandate" was entered between the electorates and the elected representatives with a view to advancing the cause of the people of Merafong, which was for the latter to remain in Merafong City Municipality. However, without consulting or updating the people of Merafong ${ }^{31}$ further, the Gauteng Provincial Legislature, ${ }^{32}$ proceeded to vote for the Amendment Bill that transferred the Merafong City Local Municipality to the North West Province. ${ }^{33}$

The Court found that there was no evidence indicating that the Gauteng Legislature had failed to consult with the people in the law-making process and therefore dismissed the applicants' case. It can be gathered from the foregoing ruling that the Court's interrogation of the appropriateness of the procedure was limited to the issue of whether or not the electorate was consulted. The Court, it does appear, glossed over, or, in fact, avoided the issue of whether the representatives advanced the views of the people so much so that these views reflected in the outcomes of the law enacted. The Court's failure to delve deeper into this issue, it is submitted, is absurd. The Court, in this case, ought to have gone beyond the procedural aspects and decided the matter based on the agreement between the parties. It is

27 Soobramoney v Minister of Health (Kwazulu-Natal) 1998 (1) SA 765 (CC) par 29. The court said, "courts will be slow to interfere with rational decisions taken in good faith by the political organs ... whose responsibility it is to deal with such matters".

282008 (5) SA 171 (CC).

29 Merafong Demarcation Forum v President of the Republic of South Africa 2008 (5) SA 171 (CC) supra par 1

30 Merafong Demarcation Forum v President of the Republic of South Africa 2008 (5) SA 171 (CC) supra par 41.

31 The electorate.

32 The elected reps.

33 Merafong Demarcation Forum v President of the Republic of South Africa 2008 (5) SA 171 (CC) supra par 58. 
submitted that the court in this case ought to have intervened as the elected representatives had raised the expectations of the electorate by entering into a negotiating mandate in that they will provide "reasoned explanations for their decisions" ${ }^{34}$ As a form of accountability, providing the electorate with reasons has benefits in that:

"First, reason-giving promotes accountability by limiting the scope of available discretion and ensuring that public officials provide public regarding justifications for their decisions. Second, reason-giving facilitates transparency, which, in turn, enables citizens and other public officials to evaluate, discuss, and criticise governmental action, as well as potentially to seek legal or political reform. Most fundamentally, reason-giving fosters democratic legitimacy because it both embodies and provides the preconditions for, a deliberative democracy that seeks to achieve consensus on ways of promoting the public good that take the views of political minorities into account."

In light of this, it is submitted that the actions of the legislature were contrary to the functions of representative democracy - that is the foundation of general elections. ${ }^{36}$ It must be highlighted that continuously facilitating public participation provides "vitality to the functioning of representative democracy". ${ }^{37}$ It encourages the electorates to be part and parcel of public matters and "enhances the civic dignity of those who participate by enabling their voices to be heard and taken account of" ${ }^{38}$ Further, public participation is a sign of people being involved in the democratic processes that enact laws. This, in turn, has the potential to produce laws that are likely to be accepted and respected by the public at large. ${ }^{39}$ Importantly, public participation "strengthens the legitimacy of legislation in the eyes of the people" ${ }^{40}$ As said by Ngcobo $\mathrm{CJ}^{41}$

"Participatory democracy is also of special importance to those who are relatively disempowered in a country like ours where great disparities of wealth and influence exist."

The aforesaid functions are therefore important in a constitutional democracy so that the electorates can have faith in those who represent them in matters that so fundamentally affect their lives. The actions of the representatives in the present case, therefore, betrayed the trust of the electorate. In these circumstances, the words of Sachs $\mathrm{J}$ ring a loud bell. This judge noted that the failure of the representatives to return to the community:

"[D]iminished the civic dignity of the majority. It denied any spirit of accommodation and produced a total lack of legitimacy for the process and its

\footnotetext{
Staszewski "Reason-Giving and Accountability" 2008-2009 93 Minnesota LR 1266

Staszewski 2008-2009 93 Minnesota LR 1278

Doctors for Life International $v$ Speaker of the National Assembly supra par 115.

Ibid.

Ibid.

Ibid.

Ibid.

As he was then.

Ibid.
} 
outcome in the eyes of the people. And finally, it gave rise to a strong perception .... that the legislative process had been a sham because an irreversible deal had already been struck at a political level outside the confines of the legislative process in terms of which, come what may, Merafong was going to go to North West."

Indeed, the failure of the elected representatives, in this case, may be viewed as a sign of dishonesty. It is as if the representatives had already made a decision that, regardless of what the wishes of the electorate were, they were going to be relocated to Merafong. Therefore, consultation was merely for the purposes of complying with the constitutional duty to facilitate public participation. As correctly observed by Moseneke J,

"Government must be open and responsive to the wishes of communities, which may not necessarily be adequately represented in national elections and could, therefore, find expression in localised resistance. But it also must act in the national interest, be loyal to those who voted it into office ...."

Moseneke proceeds by indicating that a conduct such as that of the representatives who failed to update their constituency about their change in the voting process does not per se result in the invalidity of the legislation. According to him, elected representatives who disregard their voters and/or fail to fulfil promises with no explanation "should be held accountable" through regular elections. ${ }^{45}$ I disagree with this view. It does not offer a remedy in cases such as the present one.$^{46}$ Elections come after five years. People who are about to be forcefully relocated from their location will have to wait for five years before they can hold their representatives accountable. If they are unable to hold their politicians accountable during the five-year period because of one reason or the other, they will have an unwinnable case. The implication of this for accountability is that such a lapse of time poses serious challenges for redress as certain important processes will have been overtaken by events. A case in point is the e-toll saga. In this case, the court is unlikely going to reverse a decision that has dire repercussions as seen in the e-toll case that the application was brought after a long time had passed and several developments had taken place. Additionally, if the court was really willing to give effect to the duty to facilitate public participation, it is submitted that in the present case, it should have found the entire process procedurally flawed. The basis for this submission is that there was a "negotiation mandate" that was agreed upon. At the very least, there was an expectation from the electorate that their matter would still be discussed as per the negotiating mandate. The argument presented by Bohman in that the adoption of laws in a democratic society must at least comply with three requirements is supported. ${ }^{47}$ The

43 Merafong Demarcation Forum v President of the Republic of South Africa 2008 (5) SA 171 (CC) supra par 292.

44 Merafong Demarcation Forum v President of the Republic of South Africa 2008 (5) SA 171 (CC) supra par 25 (author's own emphasis).

45 Merafong Demarcation Forum v President of the Republic of South Africa 2008 (5) SA 171 (CC) supra par 60.

46 Staszewski 2008-2009 93 Minnesota LR 1266. According to Staszewski, the notion that the government is primarily held accountable through regular elections is "wildly unrealistic".

47 Bohman Public Deliberation: Pluralism Complexity and Democracy (1996) 187. 
first, according to him, the laws must be an end product of an inclusive and transparent consultation process. ${ }^{48}$ The second is that the end product must be such that the electorate may even feel more comfortable to engage responsibly during public participation than to be given only an option to comply. ${ }^{49}$ The third is that "the source of sovereign power" is "the public deliberation of the majority" ${ }^{50}$ These three requirements were not met in this case. First, public participation was not fair and open as the negotiating mandate was unilaterally changed. Secondly, the continued deliberation was closed when the representatives opted to vote in favour of the relocation of the Merafong Municipality. Thirdly, the views of the majority to remain in Merafong were disregarded. It is submitted that this was contrary to promoting a transparent and open dialogue to ensure that the duty to facilitate public participation was discharged.

Further, as will be shown later on, in assessing the reasonableness of the actions of the elected representatives, the court was reluctant acknowledge that the behaviour of the legislature was tantamount to a failure to facilitate an open, transparent and reasonable public consultation as required by section 72(1)(a) and section 118(1)(a) of the Constitution. The court in my view placed more focus on the importance of representative democracy over participatory democracy. It did not sufficiently consider the views expressed by individuals and groups within the community.

\title{
23 Poverty Alleviation Network $v$ President of the Republic of South Africa ${ }^{51}$
}

This case dealt with the Constitution Twelfth Amendment of 2005. It altered the provincial borders and relocated the local Municipality of Matatiele from KwaZulu-Natal Province into the Eastern Cape Province. The applicants inter alia challenged the enactment of the Constitution Twelfth Amendment of 2005. The challenge was based on the alleged failure on the part of the National Assembly to receive oral submissions from affected parties. Because of this, the applicants argued that the failure amounted to noncompliance with the duty to facilitate public participation as contained in the Constitution. In addition, they contended that the National Assembly and the KwaZulu-Natal Legislature had failed to consider the submissions made by the affected people of Matatiele. It must be highlighted here that even after the Twelfth Amendment of 2005 was enacted, the people of Matatiele continued to oppose their relocations. Additionally, there were several consultations but the people remained opposed to the move. However, their elected representatives proceeded with the move and transferred them to the Eastern Cape Province. The court ruled that provincial legislatures ${ }^{52}$ had

\author{
Ibid. \\ Ibid. \\ Ibid. \\ Supra. \\ Elected representatives.
}


an unfettered discretion in determining how to facilitate public participation. ${ }^{53}$ The court further said that the fact that the views of the people of Matatiele to remain in Kwa-Zulu Natal were not reflected in the final law, ${ }^{54}$ did not mean that they were not consulted. ${ }^{55}$

In light of the foregoing discussion of the cases, it can be deduced that where the elected representatives and the electorate have conflicting views on an issue, the views of the representatives will prevail over those of the electorates. Additionally, the discussion has revealed that in reality, the views of the electorate do not carry much weight because the elected representatives reserve the discretion to act otherwise despite evidence of a prior agreement between the electorate and the elected representatives. Finally, it can also be concluded that by electing representatives, the public has given their representatives some form of leeway to act in whatever manner they deem necessary and appropriate regardless of what the electorate want or think.

\section{PARTICIPATORY DEMOCRACY PREFERRED OVER REPRESENTATIVE DEMOCRACY}

In the cases discussed in this section, the elected representatives had taken a unilateral decision and adopted certain legislation without having consulted with the people. The court emphasised the pivotal role of participatory democracy and endorsed it.

\section{Doctors for Life International $v$ Speaker of the National Assembly $y^{56}$}

The applicant, in this case, challenged the lawfulness of the Choice on Termination of Pregnancy Amendment $\mathrm{Act}^{57}$ and the Traditional Health Practitioners Act, ${ }^{58}$ on the grounds that the National Council of Provinces and the provincial legislatures did not consult with the people during the process of enacting these laws as mandated by the Constitution. ${ }^{59}$ The applicant argued that the legislatures were constitutionally mandated to gather submissions and facilitate hearings before the Choice on Termination of Pregnancy Amendment Act ${ }^{60}$ was enacted. ${ }^{61}$ The respondents denied this allegation and argued that both the National Council of Provinces and the

53 Poverty Alleviation Network v President of the Republic of South Africa supra par 35 and 56 .

54 Or that their views were not considered.

55 Poverty Alleviation Network $v$ President of the Republic of South Africa supra par 63.

56 Doctors for Life International $v$ Speaker of the National Assembly supra.

$57 \quad 38$ of 2004.

582004.

59 It must be noted that there were also other legislations such as the Sterilisation Amendment Act 3 of 2005, and Dental Technicians Amendment Act 24 of 2004 that were challenged on the basis that there was no consultation with the public. The court nonetheless found that the legislators had facilitated public participation in the aforesaid laws.

6038 of 2004.

61 See Doctors for Life International v Speaker of the National Assembly supra par 1410C. 
provincial legislatures had facilitated public participation as required by the Constitution. The respondents contended that they were required only at a certain point to provide the applicants with an opportunity to make their submissions. $^{62}$

The court inter alia had to determine whether the legislature had complied with its duty to facilitate public participation obligation when promulgating the aforesaid legislation, and, the consequences of such a failure. It found that parliament had failed to facilitate public participation when enacting the laws as required by the Constitution. It, therefore, declared them invalid.

The court emphasised that the reasonableness test is used to measure the steps taken by the Government to fulfil her constitutional obligations. ${ }^{63}$ Accordingly, reasonableness should also be applied in measuring how the legislature has complied with the duty to facilitate public participation in the law-making process. ${ }^{64}$ In assessing the reasonableness of the legislature's conduct, the nature of the legislation and its impact on the people should be taken into account. ${ }^{65}$

It is also pivotal to mention that the court in this case, inter alia, emphasised the importance of political participation in the "conduct of public affairs" as provided for under national constitutions, regional and international law. ${ }^{66}$ It further indicated that giving the public an opportunity to participate in public affairs is not a new concept, as traditional means of public participation such as imbizo and lekgotla have always been part of the South African culture. ${ }^{67}$ According to the court, these traditional methods of public participation are a "practical and symbolic part of our democratic processes". ${ }^{68}$ In the court's words, this is a form of "participatory democracy". ${ }^{69}$

The court was in all respects indicating South Africa's constitutional democracy cannot be promoted in isolation with the history of the country where the majority of the people were excluded from the law-making process. $^{70}$

The decision of the court in this case rubber-stamped the "process of direct public input back into the legislative realm". ${ }^{71}$ By doing so, it highlighted the critical role of participation in the law-making process. As has been pointed out by the author elsewhere, this "ruling demonstrated the ability of the Court to utilise the democratic principles enshrined in the Constitution in order to promote participatory democracy". ${ }^{72}$ The Court is to

\footnotetext{
Doctors for Life International v Speaker of the National Assembly supra par 1409C. Doctors for Life International $v$ Speaker of the National Assembly supra par 126. 
be commended for this approach as the decision signals a departure from South Africa's unjust history that was coupled with arbitrary legislative decisions. ${ }^{73}$

\section{Democratic Alliance v Ethekwini Municipality ${ }^{74}$}

The Ethekwini Municipality adopted a policy in order to rename certain streets and buildings within its jurisdiction. ${ }^{75}$ The policy was implemented in two phases. The first phase was taken on 28 February 2007 during which the names of ninety-nine streets were changed. The second phase occurred on 28 May 2008 with ninety-nine streets being renamed. ${ }^{76}$ The Municipal Council amended its street-naming and renaming policy during phase two. The effect of the amendment was that "the requirement of prior consultation with the addressees and affected persons during the renaming process was deleted and replaced with the requirement of consultation with ward committees". ${ }^{77}$ According to the City Manager, Dr Sutcliffe, the original policy was made during the time of "isolated renaming requests", when there were no ward committees, and that there were challenges with consulting addresses. ${ }^{78}$ The aforesaid decisions prompted the applicant to challenge the Municipality's decision on the basis that there was no proper public consultation, "no proper deliberative process took place in any of the committees of the Municipal Council itself with reference to the decisions" and that the Municipal Council had failed to adhere to its own policy regarding the street-naming policy. ${ }^{79}$ The High Court rejected the applicant's submissions on a number of grounds, one notable one being that: the Municipal Council is a deliberative legislative body whose members are elected, and that their decisions were influenced by political considerations for which they were politically accountable to the electorate. ${ }^{80}$ It held further that consultation did not guarantee that the applicants will influence the end results. The court highlighted further that consultation did take place at Council level. The applicant appealed this decision to the Supreme Court of Appeal. ${ }^{81}$

In the SCA, the appellant contended that the municipal's decisions were unlawful as they did not comply with applicable laws and that they were therefore irrational. In considering the appeal, the SCA noted that the Constitution imposed a specific duty on the National Assembly and the National Council of Provinces to facilitate public involvement in their legislative processes. ${ }^{82}$ The SCA further observed that such obligation was also imposed on the provincial legislatures as per the provisions of section

\footnotetext{
Nyati 200812 Law, Democracy and Development 10.

2012 (2) SA 151 (SCA).

Democratic Alliance $v$ Ethekwini Municipality supra par 1.

Ibid.

Democratic Alliance v Ethekwini Municipality supra par 12

Democratic Alliance v Ethekwini Municipality supra par 13.

Democratic Alliance $v$ Ethekwini Municipality supra par 15

Democratic Alliance $v$ Ethekwini Municipality supra par 19.

Hereinafter "the SCA".

Democratic Alliance v Ethekwini Municipality supra par 23.
} 
118(1) of the Constitution but not on the Municipal Councils. The SCA nonetheless concluded that Municipal Councils were required to facilitate public involvement because section 152(1)(a) of the Constitution and various provisions of the Local Government: Municipal Systems Act ${ }^{83}$ requires municipalities "to establish appropriate mechanisms ... to enable local communities to participate in municipal affairs". ${ }^{44}$

The SCA indicated further that the reasonableness test was applicable in this case in order to ascertain whether the Municipal Council had complied with its obligation to facilitate public involvement in the law-making process. It, therefore, ruled that the Municipality Council had failed to comply with its own original policy as far as phase one was concerned. The court stated inter alia that the seven-day notice provided by the Municipal Council in these circumstances was wholly inadequate because there was no urgency for the decision to be made. Additionally, it decided that members of the public should have been afforded a reasonable time period to submit, amongst others, comments and objections. ${ }^{85}$ In addition, it found that the public notices were not proper, as they did not, inter alia, invite any suggestions for alternative names. ${ }^{86}$ Overall, the court applied the reasonableness standard in arriving at the conclusion that the process in phase one failed the test for lawfulness, and had, therefore, to be set aside. ${ }^{87}$

With regard to phase two, the court found that when this process was initiated, the Municipal Council had already changed the original policy so that consultation can be done with ward committees instead of addressees. It accordingly found that the amendment was valid as proper procedures in enacting it were followed. ${ }^{88}$ There were, therefore, consultations with ward committees and the phase two process was valid.

This decision further bolsters the point that the Constitution requires elected representatives to take reasonable measures to consult with the people in the law-making process. ${ }^{89}$ This is an important feature of democracy that requires transparency and accountability.

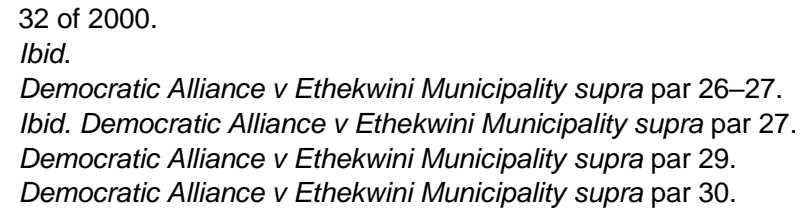

Surban "Signs of Change: The Renaming of Durban's Streets" 2011 32(3) Obiter 731. See also Kumalo "Monumentalization and the Renaming of Street Names in the City of Durban (Ethekwini) as a Contested Terrain between Politics and Religion" $225 \mathrm{https}: / /$ dspace. nwu.ac.za/bitstream/handle/10394/12858/No_70\%282014\%29_12_Kumalo_RS.pdf?seque nce $=1$ \&isAllowed $=y$ (accessed 2017-07-12).

90 Mudge and Wieser Democratic Contracts for Sustainable and Caring Societies: What can Churches and Christian Communities Do? (2000) 7. 


\section{Joseph v City of Johannesburg ${ }^{91}$}

This case concerned the disconnection of electricity supply by the City Power where the applicants were tenants in a building known as Ennerdale Mansions. There was a disconnection of electricity, however, the tenants were not given prior notice of the said disconnection. City Power had only served the notice of disconnection to the landlord who failed to alert the tenants that the electricity was about to be disconnected. The City Power By-laws are the ones that sanctioned disconnection of electricity supply to its customers and not third parties such as the tenants in this case. ${ }^{92}$ The tenants were up to date with their electricity payment because they were paying it to the landlord. ${ }^{93}$ However, the landlord did not furnish the said payments to City Power and was in arrears for an amount of R4000 000. ${ }^{94}$

The issue that had to be determined by the court was inter alia whether the tenants were entitled to notice ${ }^{95}$ before the disconnection of electricity supply by City Power. The court inter alia indicated that electricity is an important basic municipal service and that local government had a constitutional and statutory obligation to provide it. ${ }^{96}$ It further held that receiving electricity was declared to be a public law right, by virtue of constitutional and statutory obligations. ${ }^{97}$ It, therefore, concluded that the applicants were entitled to procedural fairness, which included an adequate notice of at least 14 days before disconnection. The aforementioned by-laws were declared inconsistent with the Constitution.

The aforementioned decision demonstrated the power of the court to consider the matter that involved a contractual dispute between the Municipality and the landlord in a manner that affords those who were directly affected with an opportunity to make representations and giving them adequate notice. ${ }^{98}$ The Court indicated that procedural fairness to mention but a few required the public to be "encouraged to participate in policy-making". ${ }^{99}$ The case highlights the importance of the local Municipality to comply with its constitutional obligations to consult and/or give an opportunity to those who are affected by a particular law in order to make representations. ${ }^{100}$ The decision further highlights the pivotal role played by participatory democracy in local affairs. ${ }^{101}$ The City Power had clearly failed

912010 (4) SA 55 (CC).

92 Greater Johannesburg Metropolitan Council: Standardization of Electricity By-Laws (1999); City of Johannesburg Metropolitan Municipality: Credit Control and Debt Collection By-laws (2005).

93 Joseph $v$ City of Johannesburg supra par 7.

94 Joseph $v$ City of Johannesburg supra par 8.

95 Meaningful engagement.

96 Joseph $v$ City of Johannesburg supra par 39.

Joseph $v$ City of Johannesburg supra par 47.

98 Munyai The Contribution of the Joseph Case to the Development of Procedural Fairness in the Republic of South Africa (LLM dissertation, University of Pretoria 2015) 14.

99 Joseph $v$ City of Johannesburg supra par 44.

100 Macortt "The Role of Administrative Law in enforcing Socio-economic Rights" 201339 South African Journal on Human Rights 484.

101 Currie and De Waal The Bill of Rights Handbook (2005) 667. 
to consider and apply procedural fairness in so far as the applicants were concerned.

\section{Beja v Premier of the Western Cape ${ }^{102}$}

The City of Cape Town upgraded the informal settlement of Makhaza in terms of the Silvertown Project for the Upgrading of Informal Settlements Programme. ${ }^{103}$ There was an agreement between the City of Cape Town and individual members of the community in respect of the provision of toilets. This case concerned, specifically, 55 unenclosed toilets in Makhaza. ${ }^{104}$ The applicants argued inter alia that the provision of open toilets violated their constitutional rights such as human dignity. In response to this argument, the respondents contended that the residents had agreed to enclose the toilets themselves if the City were to be in a position to provide at least one toilet for each household. In fact, most of the built toilets were enclosed by the residents themselves but not properly so because of limited financial means. ${ }^{10}$

The court noted that when the decision was made to provide the toilets, and when the tender for installations was issued, the community was not consulted. To this end, Erasmus J remarked, "I pause to note that I was not referred to any meaningful community engagement before this decision was made". ${ }^{106}$ Although the City claimed that endeavours to consult with the community were taken, the court noted with concern that there was no reference to the community attending any of the meetings. ${ }^{107}$ Further, there were no minutes to support claims that meetings, involving the community, were conducted. The court further noted that the meetings were taken two years prior to the installation of unenclosed toilets. ${ }^{108}$ This led the court to enquire, "whether the 60 people of the community who attended the meeting in 2007 were still within the community in 2009 when the unenclosed toilets were installed". The court noted that there were minutes of other meetings that were conducted. However, the said meetings were only "held to establish the site of the toilets". ${ }^{109}$ The court then said, "[n]othing about the community enclosing their own individual toilet arises out of these minutes". ${ }^{110}$ In particular, the court noted with concern that the alleged agreement between the City and Community did not mention anything about those who were unemployed and poor and as such, could not afford to enclose their own toiles. ${ }^{111}$ In this regard, the court highlighted that the standard of reasonableness in terms of section 26(2) of the Constitution requires a housing programme to be "frame[ed] in a manner that takes

\footnotetext{
[2011] 3 All SA 401.

Beja v Premier of the Western Cape supra par 11.

104 Beja v Premier of the Western Cape supra par 20.

105 Beja v Premier of the Western Cape supra par 19.

106 Beja v Premier of the Western Cape supra par 20.

107 Beja v Premier of the Western Cape supra par 82.

108 Beja v Premier of the Western Cape supra par 83.

109 Beja v Premier of the Western Cape supra par 84.

110 Ibid.

111 Beja v Premier of the Western Cape supra par 102.
} 
account of the needs of the most vulnerable and desperate". ${ }^{112}$ The court, therefore, concluded that City's agreement failed to meet minimum guidelines for agreements with communities with the aim of realising socioeconomic rights. It found that the City's action failed to meet the standard of reasonableness as required by the Constitution. Furthermore, the court confirmed there was a violation of the rights such as privacy and human dignity.

Importantly, the judgment emphasised the essence of community participation as outlined in the Upgrading of Informal Settlement Programme as well as the concept of meaningful engagement as set in the Constitution and the National Housing Code. ${ }^{113}$ The court found that there was no meaningful engagement with the community because there was no adequate notice for community representatives to consult with their constituencies. It held further that there was no information sharing with the community, and that there were no minutes.

\section{SA Property Owners Association v Johannesburg Metropolitan Municipality ${ }^{115}$}

In this case, the respondent had sought to recover the deficit in rates income, which was experienced because of successful objections by members of the public to property valuations. ${ }^{116}$ Consequently, it increased the rates on business, commercial and industrial properties by $28 \%^{117}{ }^{117}$ This was done way after the budget that provided for an increase of $10 \% .{ }^{118}$

The appellant, the South African Property Owners Association, ${ }^{119}$ aggrieved by the City's decision to unilaterally increase rates on business, commercial and industrial properties. As a result, the appellant challenged the City's decision in the South Gauteng High Court on the basis that it was inter alia in contravention of the provisions of the $\operatorname{law}^{120}$ that requires that the community participation in a decision, which amends the rates after the budget, have been tabled. ${ }^{121}$ The High Court inter alia found that there was no failure on the part of the City to engage the community. The appellants appealed this decision to the Supreme Court of Appeal. ${ }^{122}$ One of the issues to be determined by the SCA was whether the City had complied with its obligations to conduct community participation in the approval of the

112 Ibid.

113 See Tissington Basic Sanitation in South Africa: A Guide to Legislation, Policy and Practice (2011) 46 and 64.

114 Beja v Premier of the Western Cape supra par 98.

1152013 (1) SA 420 (SCA).

116 SA Property Owners Association v Johannesburg Metropolitan Municipality supra par 1.

117 SA Property Owners Association v Johannesburg Metropolitan Municipality supra par 24, 25 and 30.

118 SA Property Owners Association v Johannesburg Metropolitan Municipality supra par 1.

119 Hereinafter "SAPOA".

120 The Local Government: Municipal Finance Management Act 56 of 2003 and the Local Government: Municipal Systems Act 32 of 2000.

121 SA Property Owners Association v Johannesburg Metropolitan Municipality supra par 2.

122 Hereinafter "the SCA". 
additional budget to increase levies on business properties. The SCA found inter alia that the:

"The respondents did not give SAPOA and the rest of the business community proper notice of the new rates proposed and the short period allowed for business organisations to comment on the amended rate for business properties was completely inadequate for any person or body to properly consider the matter, do the necessary research, and prepare a meaningful representation."

It, therefore, ruled that the City had unlawfully increased the property rate levied on business commercial and industrial properties. It accordingly set the City's decision aside. This decision further emphasised the need for the local authorities to meaningfully engage those who are more likely to be affected by the proposed decision. ${ }^{124}$ Any decisions that have been taken without affording those who are more likely to be affected by it an opportunity to make a representation is therefore likely to be declared unlawful by the courts.

\section{City of Cape Town v Robertson ${ }^{125}$}

In this case, the Cape Metropolitan Area started a process that integrated sixty local authorities into a single Municipality, now known as the City of Cape Town. ${ }^{126}$ The basis for this was to do away with racially constituted local government and establish one, which was democratically constituted. Prior to this transition, each local Municipality used to conduct its own property valuations for rates based on different valuation rolls. This caused problems as it produced discrepancies between rate values and the actual values of properties. Additionally, this resulted in a perception of an unfair and discriminatory distribution of the property rates to some residents. After the establishment of the City of Cape Town, the City compiled a metropolitan wide provisional valuation roll of properties for the 2002/2003 municipal financial year in terms of the Property Valuation Ordinance of $1993 .{ }^{127}$ The "City resolved that property rates and tariffs for the 2002/2003 municipal financial year would be levied in accordance with the 2000 general valuation roll prepared".

The appellants approached the High Court for an order restraining the City of Cape Town from charging property rates based on the provisional property valuations roll that was opened for inspection in $2002 .{ }^{120}$

In the High Court, the appellants inter alia challenged the validity of the provisional valuation roll on the basis that it was not a law in force and therefore the City could not rely on it for levying rates. Further, they

23 SA Property Owners Association v Johannesburg Metropolitan Municipality supra par 40.

124 Khosa "Real Citizenship: Participation and Democracy" in Callan and Graham Democracy in the Time of Mbeki (2005) 128.

1252005 (2) SA 323 (CC).

126 City of Cape Town v Robertson supra par 9.

127 City of Cape Town v Robertson supra par 16.

128 City of Cape Town v Robertson supra par 18.

129 City of Cape Town v Robertson supra par 1. 
contended that the City could not impose rates because it was not a local authority as described by the Ordinance and that there was no legislation empowering the City to charge property rates based on a provisional valuation roll.

During the High Court proceedings, the City through the Minister of Provincial and Local Government passed an amendment to the law governing local governments and passed the Local Government Laws Amendment Act. ${ }^{130}$ The applicants amended their application in order to include a challenge to the aforesaid legislation on the grounds that the parliament had failed to facilitate public consultation as required by the Constitution. The High Court ruled in favour of the appellants and declared section 21 of the Amendment Act invalid on the grounds that it should have been published for public comment as required by the Constitution.

The respondents successfully appealed the decision of the High Court to the Constitutional Court. The Constitutional Court found that both the Local Government: Municipal Structures Act $^{131}$ and the Ordinance authorise the City to value property and to recover property rates.

The Constitutional Court did not consider the constitutionality of section 21 of the Amendment Act as the decision would not have had any practical value and that the challenge was to a large extent "different to a substantive challenge". ${ }^{132}$ It accordingly declined to confirm the order of invalidity.

The aforesaid arguably indicates an unfortunate situation where the parties were still before the court for clarity whether or not the City could charge rates based on the Ordinance, parliament passed new legislation called the Local Government: Municipal Structures Act ${ }^{133}$ without giving the appellants an opportunity to make comments. The court did not find it necessary to deal with this matter in light of the fact that it would not have changed the outcome of the case, it is submitted that the court ought to have at least cautioned pronounced itself on the problematic implications of the action of parliament to pass legislation, which does not measure up to the constitutional requirement of public participation. ${ }^{134}$

\section{AN ASSESSMENT OF ALL THE CASES}

The discussion above revealed that where the legislature has complied with its duty to facilitate public participation, it does not matter whether the public is satisfied or not with the outcome. Instead, the decision of the representatives will prevail as long as public participation was conducted in line with the requirements of the Constitutions. In this regard, the e-tolling case is an example wherein the public remains opposed to the e-tolling system but the elected representatives have chosen to go ahead with the

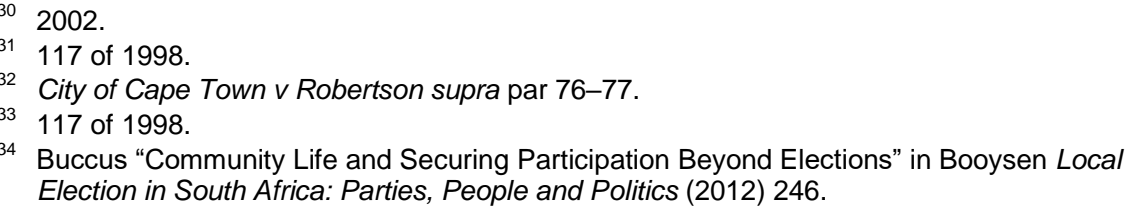


tolling of Gauteng highways. In any event, the courts have made it clear that they will not deal with the contestation of political decisions. ${ }^{135}$

With regard to the relocation of people from one province to the other against their will, it is also immaterial on what the views of the people are what is important is that the representatives must have consulted with the people. If the people are not happy with the decision of their representatives, they must live with that. The courts are not a place to deal with such issues especially where the people were fully consulted. This position was affirmed by the court, per Van Der Westhuizen J, in Merafong Demarcation Forum v President of the Republic of South Africa where he said:

"The facilitation of public involvement is aimed at the leqislature being informed of the public's views on the main issues addressed in a bill, not at the accurate formulation of a legally binding mandate.

It is not for this court to decide in which province people must live or to second-quess the option chosen by the Gauteng Provincial Leqislature to achieve its policy goals and thus to make a finding on how socially, economically or politically meritorious the Twelfth Amendment is."

As seen above, it has recently been the position of the courts that the "policy should be influenced by people's views, but such views were not necessarily the end results or legislating". ${ }^{137}$ This is where the problem is. People resort to the courts only because their representatives had ignored their views such as the introduction of the e-tolling system and the transfer of Merafong and Matatiele municipalities from one province to another. As correctly observed by Phooko, "the role of courts in enforcing public participation is limited to procedural issues and not substantive ones". ${ }^{138}$ The electorate has no remedy where their views have not been considered and/or did not influence the outcome of the law or policy.

What is more troubling with the decisions of the court where representative democracy was preferred over participatory democracy is that there was no firm position from the courts. The court did not make it clear whether or not reasons should be provided to the public about why their views were not reflected in the outcome and/or were rejected. The case between the City of Cape Town v Robertson is a testament to this concern as the court opted not to deal with the issue that related to parliament's failure to facilitate public participation in the law-making process. ${ }^{139}$ Bishop has argued that the courts preferred representative democracy because there was nothing else that it could have done when the representatives had facilitated public participation as mandated by the Constitution. ${ }^{140}$ In other words, the court did not want to venture into the sphere of the legislative

35 National Treasury v Opposition to Urban Tolling Alliance 2012 (6) SA 223 (CC) par 293.

136 Merafong Demarcation Forum v President of the Republic of South Africa 2008 (5) SA 171 (CC) supra par 114 and 59.

137 Phooko 201435 Obiter 53.

138 Phooko 201435 Obiter 57.

139 City of Cape Town v Robertson supra par 76.

140 Bishop "Vampire or Prince? The Listening Constitution and Merafong Demarcation Forum v President of the Republic of South Africa" 20092 Constitutional Court Review 313340. 
process. ${ }^{141}$ Bishop's view is to a certain extent valid in that the courts need not to unnecessary venture into the terrain of the executive. This is where my association with his view ends. It is submitted that the courts should intervene in cases such as where a negotiating mandate between the electorate and representatives was entered into. However, the representatives unilaterally changed their minds without further consulting with the people. As indicated earlier, this is in my view unacceptable and separation of powers should not be used as an excuse to prevent the courts from dealing with such cases. Perhaps it is in this regard that arguments by scholars such as Karen Czapanskiy and Rashida Manjoo warrant elaboration. These scholars are of the view that people will participate only on condition that "legislators act respectfully during hearings, make themselves open to changing their minds, and be prepared to justify their decisions in the same fair and open participatory process". ${ }^{142}$ I agree with Karen Czapanskiy and Rashida Manjoo because the electorate will have no faith in the participation process if they are given the impression that their views will in any event not influence the outcome as evident in the Merafong and Matatiele cases. It is submitted that the process of facilitating public participation in these two instances was merely to consult with the people for purposes of complying with the constitutional obligation but a decision to relocate the municipalities was already made. ${ }^{143}$ There was simply nothing that was going to change these decisions.

Another observation in the cases discussed is that the court also disregarded its own initial views indicated in Doctors for Life International $v$ Speaker of the National Assembly that representative and the participatory elements of the South African democracy should not be seen in conflict, but rather there should be a balance. It is submitted that the court did not try to strike a balance between the wishes of the electorates and their elected representatives. Instead, its approach now is that political decisions should be challenged the political sphere, not before the courts.

The cases discussed are, in my view, a clear indication that there is to some extent a conflict between participatory and representative democracies. This is especially so where the views of the electorate are dissimilar to those of their representatives. A recent example of this is the Taxation Laws Amendment $\mathrm{Act}^{144}$ and the Tax Administration Laws Amendment Act, ${ }^{145}$ which has caused a lot of controversy in workplaces. The effect of this law is that on retirement, members of, provident and retirement annuity funds inter alia may only take a certain portion of their savings upon retiring or resigning. The remaining funds would then be released to members on monthly basis. The working class and unions vehemently rejected this law as they are of the view that this was the

141 Bishop 20092 Constitutional Court Review 340.

142 Czapanskiy and Manjoo "The Right of Public Participation in the Law-Making Process and the Role of Legislature in the Promotion of this Right" 200819 Duke Journal of Comparative and International Law 19-20.

143 Bishop 20092 Constitutional Court Review 340.

14425 of 2015.

14523 of 2015. 
worker's money, and therefore the workers were entitled to take all of their savings as, and when they wish to do so. The vehement opposition to this law did not yield any positive results as the aforesaid law was enacted. The unions then promised to engage in one of the biggest protests in the country. ${ }^{146}$ It was only then that the government provided a temporary relief by postponing the operation of the said law until $2018 .^{147}$ The reality is that the Taxation Laws Amendment Act ${ }^{48}$ and the Tax Administration Laws Amendment $\mathrm{Act}^{149}$ will in all likelihood become operational because people were consulted even though they did not support the law. The laws that are not supported will nonetheless become operationalised and enforced. The question remains, how can a balance be struck between public participation and representative democracies in the law-making process in South Africa? I provide an answer to this question in the recommendations below. The recommendations will draw inspiration from the guidelines for the proposed Public Participation Act from the "Regulations on Procedures to be followed in Promoting Public Participation in Transport Planning Processes, 2012" which inter alia requires the MEC for transport (MEC) to publish a notice in the Provincial Gazette and in a minimum of two newspapers alerting the public about a first draft of the Provincial Land Transport Framework. ${ }^{150}$ Phooko has correctly noted that this is the "first piece of legislation to give content to public participation [and] is a good initiative as it spells out the procedure and time frames on what should be done in conducting public participation". ${ }^{151}$ Indeed, "other departments [and the legislature] can build on this in order to put forward a uniform policy on how public participation should be conducted". ${ }^{152}$ Even though the said regulations serve as a good example, they are nonetheless silent about the remedies available to the electorate in cases where the MEC has failed to conduct public participation. ${ }^{153}$ Additionally, they do not provide a platform for, inter alia, reconsideration of submissions where the legislature had gathered the views from the public but such views do not reflect in the outcome. These are some of the issues that the proposed legislation will seek to address.

There is one more aspect that deserves attention. It must be noted that in a democratic society, it is not always possible that the views of the majority will represent everyone and/or make every citizen happy. The minority views may in this regard be suppressed. ${ }^{154}$ All in all, "not everyone will be happy with the outcome of a deliberative process, but everyone should be happy enough with the process to have an incentive to continue to try" to persuade

146 Phago "Cosatu Threatens Strike Action Over New Tax Laws" http://www.sabc.co.za/news /a/b49dba004b7c0f24ab7bff77bc6a42c4/ Cosatu-threatens-strike-action-over-new-tax-laws20162901 (accessed 2016-01-29).

147 Presence "Government Postpones Implementation of New Tax Law" http://mg.co.za/article/ 2016-02-18-government-postpones-implementation-of-new-tax-law (accessed 2016-02-18).

14825 of 2015.

14923 of 2015.

150 Provincial Gazette for Gauteng No 266, 12 September 2013.

151 Phooko 201435 Obiter 58.

152 Phooko 201435 Obiter 41.

153 Phooko 201435 Obiter 58

154 Czapanskiy and Manjoo 200819 Duke Journal of Comparative and International Law 19. 
the elected representatives to consider the views made by the people in order to have an influence on the outcome. ${ }^{155}$

Finally, in a series of cases, it is evident that the courts are clear that in a constitutional democracy, participatory democracy is crucial especially in the law-making process. This is supported by the decisions of the court such as Democratic Alliance $v$ Ethekwini Municipality, Joseph $v$ City of Johannesburg, Beja $v$ Premier of the Western Cape, and SA Property Owners Association v Johannesburg Metropolitan Municipality, which to a large expert appear to be in favour of participatory democracy over representative democracy.

\section{RECOMMENDATIONS}

In light of the absence of clear guidelines for the form of public participation at a local government level, it is proposed that a legislation should be enacted in order to give effect to sections 59(1)(a), 72(1)(a) and 118(1)(a) of the Constitution that deals with the constitutional obligation on legislative bodies to facilitate public participation in the law-making process. The basis for this is that public participation in the law-making process is something new in South Africa since the birth of constitutional democracy. Therefore, South Africa needs legislation, regulations or some other form of guidance in the implementation of this constitutional obligation. The proposed legislation should be drafted in such a way as to ensure that the electorate is armed with a weapon to bank on to challenge processes that disregard their views. The law should equally arm representatives with criteria on how to engage the electorate as well as the implications of failure to do so for the enacted law or policy. The purpose of the legislation is inter alia to provide a standardised form that such participation should take at a local government level for facilitating public participation between the electorate and their democratically elected representatives. The proposed legislation should further, inter alia, define what public participation is, what does it entail, and how should the electorate raise their concerns in cases where their views have not been considered. This is important because the courts have been clear in that they have no role to play where the legislature has facilitated public participation. In addition, the proposed legislation should deal with issues such as conducting public workshops at a local level about the proposed law, it must also deal with draft documents that will be made available in various forms of media and in places such as local community halls for public comment, the participation procedure should be thoroughly explained in the local languages, the public must be engaged at all stages of consultation, consideration of their inputs up until the stage of the decision and there should be an avenue to endeavour to resolve disputes emanating from the final decision of the consultation process through negotiation and in a peaceful and amicable manner. 


\section{$6 \quad$ CONCLUSION}

The discussion above demonstrates a tension between participatory and representative democracy. It has also revealed that the role of the courts is only limited in dealing with procedural issues and not the content and/or outcome of the consultation process. Therefore, where the legislature has complied with its constitutional obligation to facilitate public participation, it is unable to intervene even if the representatives have disregarded the views of the people. This leaves the electorate with no remedy especially where the representatives such as in the e-tolling case, Merafong and Matatiele cases insist with the position that they have adopted. Therefore, while the court has indicated that representative and participatory democracies are not supposed to be in conflict with one other but mutually supporting. The effects of e-tolling case, Matatiele case and Merafong case are "to subordinate participation to representation". ${ }^{156}$ The preference of participatory democracy over representative democracy is testimony in the series of cases discussed above.

156 Bishop "Vampire or Prince? The Listening Constitution and Merafong Demarcation Forum v President of the Republic of South Africa" 20092 Constitutional Court Review 338. 